\title{
Confirmation of the suitability of the method of using ethanol as a reference substance for quantitative determination of volatile compounds in alcoholic beverages
}

\author{
(C) Sergey $^{1}{ }^{+}$V. Cherepitsa, Svetlana N. Sytova, ${ }^{1}$ Lidia N. Sobolenko, ${ }^{1,2}$ \\ Evgeny D. Shevchenko, ${ }^{1,2}$ Alexander Yu. Kolesnov, ${ }^{3}$ and Sergey R. Tsimbalaev ${ }^{3}$ \\ ${ }^{1}$ Laboratory of Analytical Research. Institute for Nuclear Problems of Belarusian State University. \\ Bobruyskaya St., 11. Minsk, 220006. Republic of Belarus. \\ Phone:+7 (375) 231-42-30.E-mail: siarhei.charapitsa@gmail.com \\ ${ }^{2}$ Department of Analytical Chemistry. Belarusian State University. Leningradskaya St., 14. \\ Minsk, 220006. Republic of Belarus. \\ ${ }^{3}$ Laboratory for Fundamental and Applied Research on Quality and Food Technology. \\ Peoples' Friendship University of Russia. Miklukho-Maklaya St., 8/2. Moscow, 117198. Russia.
}

\begin{abstract}
*Supervising author; ${ }^{+}$Corresponding author
Keywords: alcohol products, internal standard, ethanol, reference substance, volatile compounds, gas chromatography.
\end{abstract}

\section{Abstract}

Quality and safety control of alcohol products is an integral part of the work of laboratories for the food analysis. One of the most important safety indicators regulated worldwide is the chemical composition of an alcoholic beverages, namely the presence of characteristic and impurity volatile components. The list of controlled compounds includes acetaldehyde, methyl acetate, ethyl acetate, methyl, propyl, isopropyl, butyl, isobutyl and isoamyl alcohols, etc. Analysis of alcoholic beverages is a conservative field, since its results are closely associated with economic risks for the manufacturer, and also directly with the health of the population consuming this product. For this reason, the method, used for the analysis of alcoholic beverages, should be accurate, reproducible and simple for use. The authors have developed and described a method that satisfies the above requirements, based on the use of ethanol containing in alcoholic beverages as a reference substance for gas chromatographic analysis. Confirmation of the suitability of the proposed method for the analysis of a wide range of alcoholic beverages: whiskey, brandy, grappa, vodka, scotch tape, bourbon, brandy, calvados, sake, alcohol, rum, gin and tequila, is presented. The results, obtained by the proposed method are compared with the results obtained by the generally accepted traditional method of the internal standard using 2-pentanol. The repeatability and trueness of the both methods are evaluated. The relative difference between the results, obtained by the internal standard method, and the developed method did not exceed $2 \%$.

\section{References}

[1] GOST 30536-2013. Vodka and ethyl alcohol from food raw materials. Gas chromatographic express method for determining the content of toxic microimpurities. Moskow: Interstate Council for Standardization, Metrology and Certification. 2013. 21p. (russian)

[2] GOST 33408-2015. Cognac, cognac distillates, brandy. Determination of aldehydes, esters and alcohols by gas chromatography. Minsk: Eurasian Council for Standardization, Metrology and Certification. 2015. $18 \mathrm{p}$.

[3] GOST 33834-2016. Wine production and raw materials for its production. Gas chromatographic method for determining the mass concentration of volatile components. Minsk: Eurasian Council for Standardization, Metrology and Certification. 2016. 15p.

[4] STB GOST R 51698-2001. Belorussian State Standard 51698-2001. Vodka and ethyl alcohol. Gas chromatographic express method for determining the content of toxic microimpurities. Minsk: State Standard of the Republic of Belarus. 2001. 37p.

[5] OIV-MA-BS-14: R2009 Compendium of international methods of analysis of spirituous beverages of vitivinicultural origin. Determination of the principal volatile substances of spirit drinks of viti-vinicultural origin. International Organization of Vine and Wine (OIV). 2009. 12p. 
[6] EC 2870/2000 Community reference methods for the analysis of spirits drinks. The commission of the European communities. 2002. 47 p.

[7] GB/T 11858-2008 Vodka. Beijing: National Standards of People's Republic of China. 2008. 10p

[8] BIS IS 3752 : 2005(R2009) Alcoholic drinks - Methods of test. New Delhi: Bureau of Indian Standards. 2005. 19p.

[9] S.V. Cherepitsa, S.M. Bychkov, A.N. Kovalenko, A.L. Mazanik, N.M. Selemina, O.B. Seredinskaya. The Use of the Major Component (Solvent) As an Internal Standard in the Gas Chromatographic Determination of Impurities. J. Analyt. Chem. 2003. Vol.58. No.4. P.368-371. (russian)

[10] S.V. Cherepitsa. Using ethanol as internal standard for determination of impurities in vodka and ethyl alcohol. Conformity Assessment Methods. 2009. No.3. P.36-40. (russian)

[11] S.V. Charapitsa, A.N. Kovalenko, A.L. Mazanik, N.M. Makoed, S.N. Sytova, N.I. Zayats, N.V. Kulevich. Quantitative determination of the content of trace elements in alcoholic beverages using ethanol as an internal standard. Food Industry Science and Technology. 2012. No.2. P.86-94. (russian)

[12] Direct Determination of Volatile Compounds in Spirit Drinks by Gas Chromatography. S.V. Charapitsa [et al.]. J. Agric. Food. Chem. 2013. Vol.61. No.12. P.2950-2956. https://doi.org/10.1021/jf3044956

[13] S.V. Cherepitsa, S.N. Sytova, M.A. Zakharov, V.A. Peschanskaya, T.I. Guguchkina, M.G. Markovskii, Yu.F. Yakuba. New method of quantitative determination of impurities of alcoholic production using gas chromatography. Winemaking \& Viticulture. 2015. No.2. P.12-16. (russian)

[14] S.V. Charapitsa [et al.]. The Establishment of Metrological Characteristics of the Method 'Ethanol as Internal Standard' for the Direct Determination of Volatile Compounds in Alcoholic Products. J. Chem. Metrol. 2018. Vol.12. No.1. P.59-69. http://doi.org/10.25135/jcm.14.18.02.063

[15] Customs regulation of EAEU 047/2018. On the safety of alcohol. 2018. 129p. Available at: https://docs.eaeunion.org/docs/ru-ru/01421305/cncd_10122018. (Accessed 04 January 2021)

[16] S. Charapitsa [et al.]. Single-Laboratory Validation of a Gas Chromatographic Method of Direct Determination of Volatile Compounds in Spirit Drinks: Need for an Improved Interlaboratory Study. $J$. AOAC Int. 2019. Vol.102. No.2. P.669-672. https://doi.org/10.5740/jaoacint.18-0258

[17] S.V. Charapitsa, S.N. Sytova, V.V. Egorov, S.M. Leshchev, A.L. Korban, L.N. Sobolenko, D.A. Milochkin, V.S. Ustyugov, V.A. Korobov, D.R. Ismagilov. Validation of the Method of Direct Determination of the Quantitative Content of Volatile Components in Alcohol Containing Products. Beer and beverages. 2019. No.4. P.41-45. (russian). https://doi.org/10.24411/2072-9650-2019-10005

[18] J. Kelly [et al.]. Gas Chromatographic Determination of Volatile Congeners in Spirit Drinks: Interlaboratory Study. J. AOAC Int. 1999. Vol.82. No.6. P.1375-1388.

[19] S. Charapitsa [et al.]. Interlaboratory Study of Ethanol Usage as an Internal Standard in Direct Determination of Volatile Compounds in Alcoholic Products. BIO Web of Conferences 42nd World Congress of Vine and Wine, Geneva. 2019. Vol.15. 8p. https://doi.org/10.1051/bioconf/20191502030

[20] ASTM D4307-99 Practice for preparation of liquid blends for use as analytical standards. Philadelphia, PA, USA. 2010. 3p.

[21] State Standard 3639-79. Water-alcohol solutions. Methods for determining the concentration of ethyl alcohol. Moscow: State Standard of USSR. 1979. 11p. (russian)

[22] STB ISO 5725 Belorussian State Standard 5725, Parts 1-6. Accuracy (Trueness and Precision) of the methods and results of measurements. Minsk: State Standard of the Republic of Belarus. 2002. (russian) 